Industrial Health, 1984, 22, 97-106.

\title{
A Long-term Survey of Environmental, Blood and Urine Mercury Levels and Clinical Findings in Workers Manufacturing Mercury Relays
}

\author{
Enrique GONZALEZ-FERNANDEZ,* Javier MENA, \\ Manuel DIAZ-GONZALEZ and Jose Maria \\ MARTINEZ-GIL DE ARANA \\ Instituto Nacional de Seguridad e Higiene en el Trabajo \\ Centro de Investigacion y Asistencia Tecnica \\ C/Torrelaguna, 73-Madrid-27 (Spain)
}

(Received December 9, 1983 and in revised form March 12, 1984)

\begin{abstract}
The correlations between airborne concentration of mercury found and the clinical and biological manifestations in workers engaged in the manual manufacture of mercury glass bubble relays has been studied. The workplace sampled was a small room in which there were five workers. Airborne mercury sampling was performed by using charcoal tubes and $3 \mathrm{M}$ mercury vapor monitors. Whole blood mercury concentration ( $\mathrm{HgB}$ ), ALA-D activity, free erythrocyte porphyrin IX (FEP), and the urinary output of mercury $(\mathrm{HgU})$ were determined for each worker. Clinical examination revealed a tremor in the hands, a metallic taste and headaches. Workers with $\mathrm{HgU}$ higher than $400 \mu \mathrm{g} / \mathrm{L}$ were orally treated with $\mathrm{N}$ acetyl-d, $l$-penicillamine, and temporary removal of them from exposure was recommended. A very good linear correlation of environmental concentrations of mercury as time weighted average (TWA) between charcoal tubes and $3 \mathrm{M}$ monitors was found. The regression analysis for the results obtained as TWA and the biological parameters measured fit a logarithmic equation well, as well as the values obtained for $\mathrm{HgB}$, ALA-D and $\mathrm{HgU}$ when they were compared.

Key words: Biological parameters-Environmental Hazards-Mercury poisoningUrine mercury after $\mathrm{CaNa}_{2}$ EDTA-N-acetyl-d, $l$-Penicillamine treatment-Mercury in whole blood and urine-Mercury in air
\end{abstract}

\section{INTRODUCTION}

Very well documented papers have been written $^{1-5)}$ dealing with absorption and excretion of organic and metallic mercury vapor in man and, more recently, these have been improved with pharmacokinetics data (distribution, clearance,

* To whom the correspondence should be addressed. Mention of company names or products does not constitute endorsement by the Instituto Nacional de Seguridad e Higiene en el Trabajo. 
excretion and metabolism ${ }^{6-8)}$ ) and dose-response relationship between environmental exposure to mercury and clinical observation. ${ }^{9,10)}$ Approximately $80 \%$ of inhaled mercury vapor is retained in the lungs. Once absorbed into the blood stream, it is rapidly oxidized to ionic mercury. Absorption of inorganic mercury compounds may be $15 \%$ or less whereas gastrointestinal absorption of methylmercury compounds are practically complete. ${ }^{11)}$ The distribution of mercury between red cells and plasma depends upon the form of mercury. The red cell to plasma ratio is highest for methylmercury (approximately 10) and lowest for inorganic mercury (approximately 1) in man. On a group basis, mercury excretion in urine is proportional to the TWA air concentration. Urinary excretion could be described by a two-term exponential equation with rate constants equivalent to half-times of 2 and 70 days. The short half-time compartment accounted for about $20-30 \%$ of the excretion rate under conditions of steady state excretion. It seems, however, that the biological half-time for the greatest part of retained salts of inorganic mercury has an average value of about 40 days. $^{\left.{ }^{7,12}\right)}$ In contrast, observations of experimental animals indicate that the pattern of elimination of mercury after exposure to mercury vapor, inorganic mercury salts, and the phenyl and methoxyethyl compounds, is dose- and timedependent and follows nonlinear pharmacokinetics. ${ }^{11)}$ The information on biological half-times in man suggests that a workman exposed to a constant average concentration of mercury vapor in his working environment would not reach a state of balance (steady state) until after one year of exposure. Consequently, one would expect the concentrations of mercury in blood or urine to exhibit a consistent relationship to air levels after the worker had been exposed for at least one year. Most effects of mercury vapor are reversible upon cessation of exposure, although complete recovery from the psychological effects is difficult to determine. Recovery may be accelerated by treatment with penicillamine and Unithiol (2,3-dimercaptopropansulfonate). The use of 2,3-Dimercapto-1-propanol (BAL) is contraindicated in cases of methylmercury poisoning as it leads to increased brain levels of mercury.

According to the man-mercury kinetic support mentioned above, this paper gathers the results and correlations obtained between airborne concentration of mercury and the clinical and biological manifestations in workers handling metallic mercury as well as the regression analysis between parameters studied. A report of the results obtained after workers' treatment with a quelation therapy is also given.

\section{EXPERIMENTAL}

\section{Subjects and treatment}

Five workers exposed to mercury vapor for various lengths of time, all of them manifested some clinical symptoms of mercury poisoning, were clinically and 
biologically monitored and medically interviewed. They were employed in a factory manufacturing mercury glass bubble relays and the workplace has an area of $18 \mathrm{~m}^{2}$ which represents an air volume of $44 \mathrm{~m}^{3}$. The workers did not wear respirators and the worklace does not have any local exhaust ventilation. Blood samples $(\simeq 10 \mathrm{~mL})$ were taken from the antecubital vein with a syringe and transferred into heparinized tubes. Urine specimens $(\simeq 500 \mathrm{~mL})$ were collected at the time of the survey in polyethylene flasks without any preservatives, and analysed immediately.

None of the exposed subjects had a previous history of occupational exposure to lead or of exposure to mercury containing drugs, but all of them had 5 to 7 years exposure to mercury in this job. None of them had a record of alcohol abuse, and none consumed alcohol at the time of sampling. Whole blood mercury concentration $(\mathrm{HgB})$, deltaaminolevulinic acid dehydratase (ALA-D) activity, free erythrocyte protoporphyrin IX (FEP) per red blood cell, and the urinary output of mercury $(\mathrm{HgU})$ were determined for each worke. The fecal mecury excretion was not measured.

Three patients were assayed for a mercury mobilization test after i.m. single dose $\mathrm{CaNa}_{2}$-EDTA $0.65 \mathrm{~g}$ injection, but all of them were treated with multiple oral doses of $0.5 \mathrm{~g}$ of $\mathrm{N}$-acetyl-d, 1-penicillamine, 4 times daily for two months.

\section{Air monitoring}

Personal samples of mercury vapor were collected in charcoal tubes from Mine Safety Appliances Co. Pittsburgh, Pennsylvania (MSA Mercury Vapor Sampling Tubes. Part. No. 459003) and analyzed by atomic absorption spectrophotometry using the procedure published by Moffit and Kupel. ${ }^{13)}$ Side-by-side personal samples of ambient air were taken with $3 \mathrm{M}$ mercury passive monitors (3M Brand, Mercury Vapor Monitor No. 3600. St. Paul, Minnesota). These were sent to 3M Laboratories for their analysis.

\section{Apparatus and analysis}

An Atomic Absorption Spectrophotometer Perkin Elmer Mod. 360, mercury EDL and EDL power supply was used. For air sample analysis, the sampling boat system was installed. For biological sample mercury analysis, the Kit Mod. 65 vapor generation accessory from Varian was connected with polyvinylchloride tubing of minimum convenient length as a cold vapor source. The burner head was removed and the absorption cell positioned in the light path. The vapor generation unit was used according to instructions described in the operation manual. ${ }^{14)}$ Peak height was measured in an integration time of 10 seconds on the meter of the spectrophotometer and recorded on the printer. $\mathrm{HgB}$ and $\mathrm{HgU}$ were analyzed by using this Kit according to the method described by Kranse et $a l .{ }^{15}$ ) At the same time, commercially available mercury in blood and urine control samples were analyzed routinely with each batch of samples. 
A Beckman Mod. Acta C-III spectrophotometer for the determination of ALA-D activity, ${ }^{16)}$ and a Perkin Elmer Mod. MPF-3 L spectrofluorometer for the determination of $\mathrm{FEP}^{17}$ ) were used. FEP determination is under constant control in the EP proficiency testing Center for Disease Control (CDC) of Atlanta, U.S.A. interlaboratory program.

\section{Reagents}

All reagents were of analytical grade and used according to the analytical methods referenced. Deionized water from a Milli-Q System (Millipore Iberica, S.A. Madrid, Spain), was used in the preparation and dilution of all solutions.

\section{Results AND Discussion}

Table 1 summarizes the results, obtained from the analysis of the control blood and urine samples, in mean values found in this survey. For control blood samples, we obtained a mercury mean recovery of $106 \%$, and for control urine samples, the mercury mean recovery was $102 \%$. Table 2 shows the results in mean values obtained in personal sampling and biological monitoring of the workers. These data are divided into three groups. Values in group A are for workers having up to 7 years of exposure, values in group $\mathbf{B}$ are for a period of time in which these workers were under lower environmental mercuy concentrations, and values in group $\mathrm{C}$ are for workers at hire time. Both air mercury concentrations expressed as TLV-TWA in $\mathrm{mg} / \mathrm{m}^{3}$, and biological parameters in mean values and range for the five workers monitored, were surveyed for each date. Two sets of personal

Table 1. Results of mercury in control blood and urine samples

\begin{tabular}{|c|c|c|c|}
\hline \multirow[b]{2}{*}{ Control blood samples } & \multicolumn{3}{|c|}{ Mercury values $\mu \mathrm{g} / \mathrm{L}$} \\
\hline & $\begin{array}{l}\text { Assigned (range) } \\
\text { or } \pm \text { STD }\end{array}$ & Found $^{c)} \pm S T D$ & Recovery \% \\
\hline $\begin{array}{l}\text { Control blood for metals } 1^{\text {a }} \\
\text { Lot. No. } 620301\end{array}$ & $10.6(8.0 \sim 13.2)$ & $11.5 \pm 0.8$ & 108 \\
\hline $\begin{array}{l}\text { Control blood for metals } 2^{\text {a) }} \\
\text { Lot. No. } 620401\end{array}$ & $90.2(81.9 \sim 98.5)$ & $93.6 \pm 7.5$ & 104 \\
\hline \multicolumn{4}{|l|}{ Control urine samples } \\
\hline $\begin{array}{l}\text { Lanonorm metals } 1^{\text {a) }} \\
\text { Lot. No. } 625201\end{array}$ & $11.8(9.8 \sim 13.7)$ & $14.1 \pm 4.7$ & 119 \\
\hline $\begin{array}{l}\text { Lanonorm metals 2a) } \\
\text { Lot. No. } 625301\end{array}$ & $114(101 \sim 128)$ & $109 \pm 8$ & 96 \\
\hline $\begin{array}{l}\text { Uri-Chem Level II }{ }^{\mathrm{b})} \\
\text { Lot. No. 2935-847 }\end{array}$ & $77 \pm 13$ & $71 \pm 11$ & 92 \\
\hline \multicolumn{4}{|c|}{$\begin{array}{l}\text { a) Commercially available from Behring Institute (Behring Werke, A. G. Medizinische } \\
\text { Abteilung, D-3550 Marburg-Lahn-1, Germany). } \\
\text { b) Commercially available from Fisher Scientific Co. Diagnostics Div. Orangeburg, } \\
\text { N. Y. } 10962 \text {. }\end{array}$} \\
\hline
\end{tabular}


Table 2. Data for mercury health hazard evaluation

\begin{tabular}{|c|c|c|c|c|c|c|c|c|}
\hline \multicolumn{5}{|c|}{$\begin{array}{c}\text { Personal Sampling } \\
\text { Mercury Concentration as TWA mg } / \mathrm{m}^{3}\end{array}$} & \multicolumn{4}{|c|}{$\begin{array}{l}\text { Biological Monitoring } \\
\text { Mean Values and (Range) }\end{array}$} \\
\hline \multicolumn{3}{|c|}{$\begin{array}{l}\text { Sampling and } \\
\text { Survey data }\end{array}$} & $\begin{array}{c}\text { MSA- } \\
\text { Charcoal } \\
\text { Tubes }\end{array}$ & $\begin{array}{c}\text { 3M- } \\
\text { Monitorb) }\end{array}$ & $\begin{array}{l}\text { Hg-Blood } \\
\mu \mathrm{g} / 100 \mathrm{~m} l\end{array}$ & $\begin{array}{l}\text { Hg-Urine } \\
\mu \mathrm{g} / \mathrm{L}\end{array}$ & $\begin{array}{l}\text { ALA-D } \\
\text { U/L } /^{c}\end{array}$ & $\begin{array}{c}\text { FEP } \\
\mu \mathrm{g} / \mathrm{L} \text { RBC }\end{array}$ \\
\hline \multirow{4}{*}{ A } & & & & & \multicolumn{4}{|c|}{ Workers With 5 to 7 years of exposure } \\
\hline & December & 1979 & 0.24 & 0.25 & $\begin{array}{c}8.1 \\
(5.2 \sim 11.3)\end{array}$ & $\begin{array}{c}542 \\
(420 \sim 640)\end{array}$ & $\begin{array}{l}22.5 \\
(19.2 \sim 27.3)\end{array}$ & $\stackrel{507}{(424 \sim 597)}$ \\
\hline & March & 1980 & 0.72 & 0.80 & $\begin{array}{ll} & 12.4 \\
(9.1 \sim 15.6) & \end{array}$ & $\begin{array}{c}979 \\
(875 \sim 1100)\end{array}$ & $\begin{array}{c}18.5 \\
(15.3 \sim 20.4)\end{array}$ & $(355 \sim 505)$ \\
\hline & April & 1980 & $\begin{array}{ll}0 & 0.2 \\
& 0.28\end{array}$ & $\begin{array}{l}0.2 \\
0.2\end{array}$ & $(3.5 \sim 5.2)$ & $\begin{array}{c}466 \\
(380 \sim 625)\end{array}$ & $\begin{array}{c}27.8 \\
(22.1 \sim 33.6)\end{array}$ & $\begin{array}{c}974 \\
(845 \sim 1118)\end{array}$ \\
\hline \multirow[b]{2}{*}{ B } & June & 1980 & 0.11 & 012 & $(0.9 \sim 1.7)$ & $(110 \sim 205)$ & $\begin{array}{c}40.8 \\
(37.4 \sim 46.3)\end{array}$ & $\begin{array}{c}743 \\
(560 \sim 908)\end{array}$ \\
\hline & September & 1980 & 0.09 & 0 & $\begin{array}{c}0.7 \\
(0.3 \sim 0.9)\end{array}$ & $\left(63 \sim^{84} 97\right)$ & $\begin{array}{c}40.0 \\
(35.3 \sim 45.2)\end{array}$ & $\begin{array}{c}949 \\
(835 \sim 1060)\end{array}$ \\
\hline & & & & & \multicolumn{4}{|c|}{ Workers at hire time } \\
\hline \multirow{3}{*}{ C } & October & 1980 & $\begin{array}{ll}0 & 0.13 \\
& 0.16^{\mathrm{a}}\end{array}$ & $\begin{array}{l}0.12 \\
0.16\end{array}$ & $(0.2 \sim 0.7)$ & $\left(22 \sim^{25} 33\right)$ & $\begin{array}{c}37.6 \\
(31.7 \sim 40.5)\end{array}$ & $\begin{array}{c}378 \\
(293 \sim 461)\end{array}$ \\
\hline & December & 1980 & 0.64 & 0.71 & $\begin{array}{c}3.1 \\
(2.7 \sim 4.2)\end{array}$ & $\left(31 \sim^{39} 45\right)$ & $\begin{array}{c}22.0 \\
(18.6 \sim 26.1)\end{array}$ & $\begin{array}{c}586 \\
(475 \sim 680)\end{array}$ \\
\hline & February & 1981 & 10.35 & 0.41 & $\begin{array}{c}3.0 \\
(2.1 \sim 3.8)\end{array}$ & $(50 \sim 64)$ & $\begin{array}{c}27.7 \\
(21.0 \sim 32.5)\end{array}$ & $\begin{array}{c}552 \\
(430 \sim 672)\end{array}$ \\
\hline
\end{tabular}

a) Grab Sample measurements, all others are partial period consecutive sample measurements.

b) Sampled period $=75 \%$ of the full shift.

c) $1 \mathrm{U} / \mathrm{L}=1 \mu \mathrm{mol}$ of ALA-D $/ \mathrm{min} / \mathrm{L} \mathrm{RBC}$.

grab samples (17 samples and 5 samples of 15 minutes each) were taken with charcoal tubes in April and October 1980, and all others were partial period consecutive samples. Personal sampling taken with $3 \mathrm{M}$ mercury monitors constituted $75 \%$ of the full work shift. As can be seen, during the follow-up survey, all the environmental mercury values were above the OSHA standard of $0.1 \mathrm{mg} / \mathrm{m}^{3}$. A lognormal distribution is assumed for the variability of individual grab samples taken at random intervals. In Fig. 1, the representation of measurements from the grab samples in the classification exposure chart $^{18}$ can be seen at $95 \%$ confidence level, showing a situation of noncompliance with the established standard. The decision chart contains the following: A vertical axis for the mean common logarithms, denoted by $\bar{Y}$, of the relative concentrations (Xi). The relative concentrations were obtained dividing each of the concentration measurements by the OSHA standard of $0.1 \mathrm{mg} / \mathrm{m}^{3}$. A horizontal axis for sample standard deviation, denoted by $\sigma$. A set of curves which form the boundaries to the noncompliance, possible overexposure, and compliance decision regions. Each of these boundaries is a function of the number of observations, denoted by $n$. The result of plotting the decision variables $\bar{Y}, \sigma$, and $n$ for each set of personal grab samples taken in April and October 1980 are show in Fig. 1. 


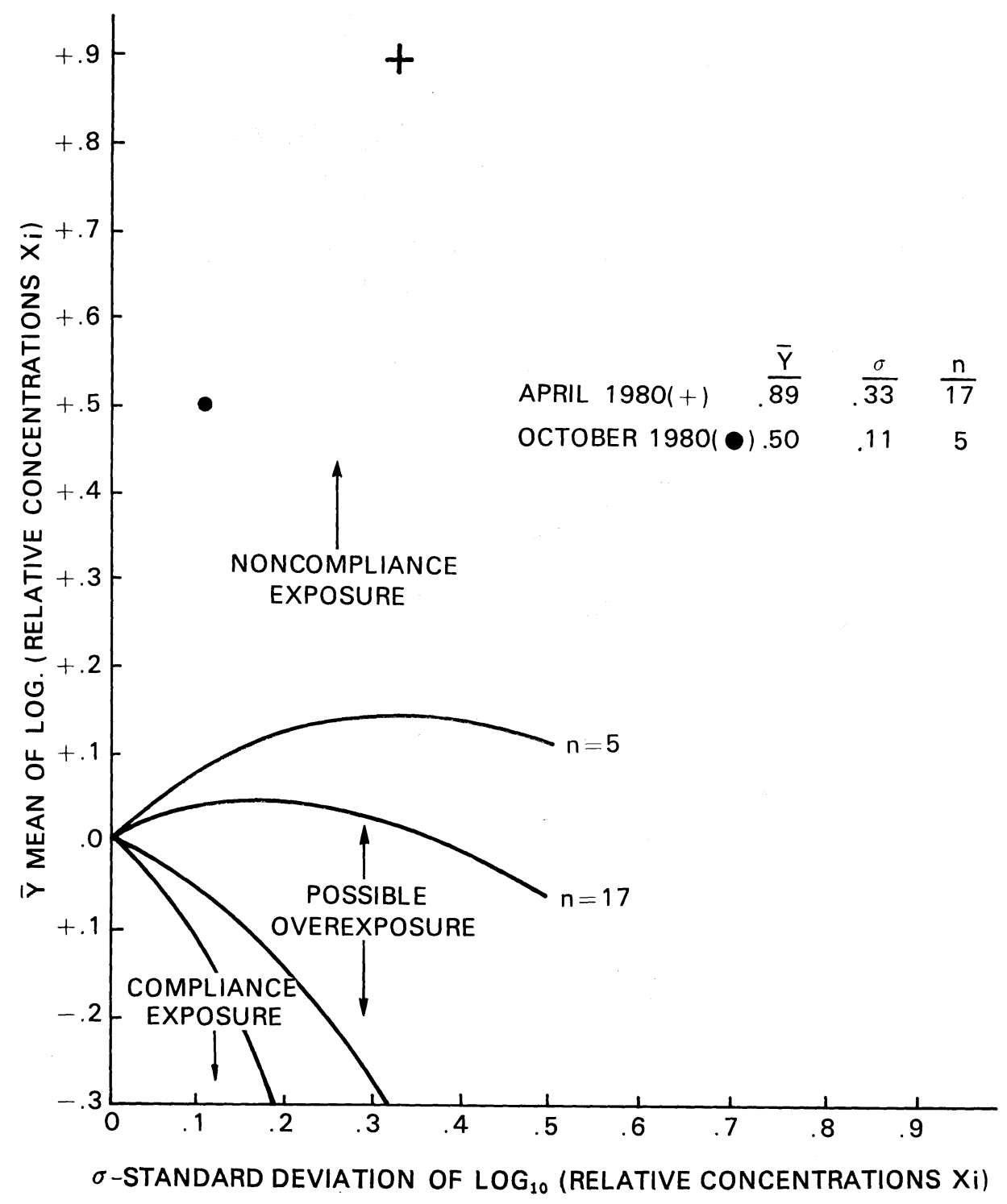

Fig. 1. Grab sample measurement average classification chart.

It is observed that in these two cases the "noncompliance exposure" choice must be made. From the mean values obtained for biological monitoring of workers having up to 7 years of exposure, we can observe that most of the values of mercury in blood and urine (A in Table 2) were higher than $3.5 \mu \mathrm{g} / 100 \mathrm{~mL}$ and $150 \mu \mathrm{g} / \mathrm{L}$ (values established respectively as a BTLV). No limit values have been determined as yet for ALA-D and FEP. The mean values of mercury in 
the blood and urine of the workers at hire time, were well below the established limit, but two months after this time ( $\mathrm{C}$ in Table 2$)$, they increased. The mean values of ALA-D and FEP were normal for these workers. It is interesting to point out that from June to September 1980 (B in Table 2), the environmental mercury concentrations decreased up to $0.08 \mathrm{mg} / \mathrm{m}^{3}$ as a consequence of less daily activity, about $30-40 \%$, in the manufacturing of relays. This situation correlated well with the mean concentrations of $\mathrm{HgB}$ and $\mathrm{HgU}$ found, and it also showed a blood cell ALA-D reactivation, with values near those of workers at hire time. However, the values for FEP, still in the same order as at the beginning of this survey, look like the values obtained in lead poisoning. ${ }^{19)}$ The disturbance in porphyrin metabolism, in workers exposed to mercury, was not so remarkable as in workers exposed to lead. However, the correlation between blood and urinary levels and environmental mercury is statistically significant. Furthermore, ALA-D activity showed a great decrease among workers who excreted more than $400 \mu \mathrm{g} / \mathrm{L}$ of mercury in urine, though the decrease was much less than the level reported by $\mathrm{Tola}^{20)}$ in lead poisoning. The decreased activity of ALA-D was not so prominent as in lead poisoning, perhaps due to the fact mercury is potent but it is a non-specific in vivo enzyme poison. While both mercury and lead have high affinities for sulfhydryl groups in vitro, they sometimes behave quite differently in biological systems in vivo.

Table 3 shows the correlations found between environmental and biological data. The correlation found for mercury in air as TWA, between samples taken with charcoal tubes and $3 \mathrm{M}$ mercury monitors, is linear with a precision coefficient $\left(\mathrm{r}^{2}\right)$ of 0.9946 and it is significant against zero at $95 \%$ confidence level. The correlations found between environmental mercury and $\mathrm{HgB}$ and $\mathrm{HgU}$ are logarithmic with good precision coefficients. The best fitting equations for experimental points of inter-biological parameters studied were; logarithmic for $\mathrm{HgB}$ and $\mathrm{HgU}$ vs. ALA-D, exponential for $\mathrm{HgB}$ vs. FEP and power for ALA-D vs. FEP. In the last two cases, a lower precision coefficient was obtained, but it is still significant against zero at $95 \%$ confidence level.

At the end of September 1980, workers having 5 to 7 years of exposure were

Table 3. Correlation between environmental and biological data

\begin{tabular}{llcc}
\hline \multicolumn{1}{c}{ Correlated Parameters } & Equations & \multicolumn{2}{c}{ Statistics } \\
\cline { 3 - 4 } & & $\mathrm{r}^{2}$ & $\mathrm{r} \neq 0$ at $\mathrm{p}<0.05$ \\
\hline TWA (Ch. Tub.) vz TWA (3 M) & $\mathrm{Y}=1.15 \mathrm{X}-0.03$ & 0.9946 & + \\
TWA vz HgB & $\mathrm{Y}=14.3+5.8 \ln \mathrm{X}$ & 0.9158 & + \\
TWA vz HgU & $\mathrm{Y}=1122+433 \ln \mathrm{X}$ & 0.9941 & + \\
HgB vz ALA-D & $\mathrm{Y}=42.2-9.7 \ln \mathrm{X}$ & 0.9958 & + \\
HgB vz FEP & $\mathrm{Y}=1063 \mathrm{e}^{-0.07 \mathrm{x}}$ & 0.7174 & + \\
HgU vz ALA-D & $\mathrm{Y}=76.7-8.4 \ln \mathrm{X}$ & 0.9539 & + \\
ALA-D vz FEP & $\mathrm{Y}=40.5 \mathrm{X}^{0.84}$ & 0.6181 & + \\
\hline
\end{tabular}


Table 4. Three cases illustrating the effects of $\mathrm{CaNa}_{2}$-EDTA

\begin{tabular}{cccc}
\hline Patients & Test Order & HgU Basal $\mu \mathrm{g} / \mathrm{L}$ & HgU-EDTA $^{\text {a) }}$ 24h $\mu \mathrm{g} / \mathrm{L}$ \\
\hline 1 & 1st & 284 & 238 \\
& 2nd & 158 & 89 \\
2 & 1 st & 542 & 434 \\
& 2nd & 375 & 287 \\
3 & 1 st & 141 & 70 \\
& 2nd & 84 & 130 \\
\hline
\end{tabular}

a) After $0.65 \mathrm{~g}$ i.m. single dose.

removed from their workplace. New workers were hired and observed for three months. In this case, no correlations were found between mercury air concentration and biological parameters because it is well known, according to the pharmacokinetic data of mercury in man that this situation will not reach a steady-state until after one year of exposure. This study was completed by a follow-up medical survey conducted on three of the five workers with 5 to 7 years of exposure, in order to see the mobilization effect of $\mathrm{CaNa}_{2}$-EDTA after $0.65 \mathrm{~g}$ i.m. single dose injection. Results in Table 4 show no effect in the mercury output after 24 hours, practically in all cases there was no mobilization yield of mercury by $\mathrm{CaNa}_{2}$-EDTA administration in the two tests realized at different times along the survey. The difference between the first and the second mobilization tests for each worker assayed, was two months. Concerning this point, it is interesting to indicate that Woodcock, ${ }^{21)}$ years ago, obtained good results in mobilization of the body burden of mercury by a five-day course of i.v. $\mathrm{CaNa}_{2}$-EDTA, $3 \mathrm{~g}$ daily. Therefore, the five workers were orally treated with $0.5 \mathrm{~g}$ doses of $\mathrm{N}$-acetyl-d, 1 penicillamine, 4 times daily for two months, since only this and not d-penicillamine increases the urinary excretion of mercury in chronic mercury vapor intoxication. ${ }^{22}$ After 10

Table 5. Clinical symptoms observed

\begin{tabular}{|c|c|c|c|c|c|c|c|c|}
\hline \multirow{2}{*}{ Patients } & \multicolumn{2}{|c|}{ Tremor } & \multirow{2}{*}{$\begin{array}{c}\text { Bimanual } \\
\text { Coord. }\end{array}$} & \multirow{2}{*}{$\begin{array}{l}\text { Conjunc- } \\
\text { tivitis }\end{array}$} & \multirow{2}{*}{$\begin{array}{l}\text { Nystag- } \\
\text { mus }\end{array}$} & \multirow{2}{*}{$\begin{array}{l}\text { Excessive } \\
\text { Salivation }\end{array}$} & \multirow{2}{*}{$\begin{array}{l}\text { Tooth } \\
\text { Spots }\end{array}$} & \multirow{2}{*}{$\underset{\text { Legs }}{\text { Cramps }}$} \\
\hline & Hands & Mandible & & & & & & \\
\hline 1 & $H$ & + & H & + & + & - & - & + \\
\hline 2 & $H$ & + & $H$ & - & - & $H$ & $H$ & - \\
\hline 3 & + & - & H & + & + & - & + & - \\
\hline 4 & + & - & + & - & + & + & + & + \\
\hline 5 & H & + & + & + & + & + & - & - \\
\hline \multicolumn{9}{|c|}{$\begin{array}{l}\text { After treatment with } \mathrm{N} \text {-acetyl-d, } l \text {-Penicillamine }(2.0 \mathrm{~g} / \mathrm{day}) \\
\text { multiple oral doses }\end{array}$} \\
\hline 1 & + & - & - & - & - & - & - & - \\
\hline 2 & - & - & + & - & - & - & - & - \\
\hline 3 & + & - & - & - & - & - & - & - \\
\hline 4 & + & - & + & - & - & - & - & - \\
\hline 5 & - & - & - & - & - & - & - & - \\
\hline
\end{tabular}


days of this treatment, one of the patients showed side effects, such as, fever $\left(39^{\circ} \mathrm{C}\right)$, chills, rash, loss of ability to taste and difficulties to urinate. Then, treatment was changed to 2 daily $0.500 \mathrm{~g}$ oral doses till the 2 months were up.

Table 5 shows the most outstanding clinical symptoms observed in the five workers. The yellow tooth spots present in three of the five workers, and not reported before by any other author, was new for us. Other symptoms, less specific, such as, irritability, fatigue, headaches, vomiting, etc. were not considered. Figures on mercury excretion during treatment showed an initial rise and a subsequent dramatic fall, and at the same time a rapid improvement in the clinical symptoms was brought about.

On the basis of environmental and medical findings gathered in this investigation, we concluded that a health hazard existed from exposure to mercury at this workplace. Therefore, recommendations on ventilation engineering controls, work practices, and if necessary, a change of steps in this manual manufacturing procedure of relays have already been made to alleviate this hazard.

\section{REFERENCES}

1) Goldwater, L. J., Jacobs, M. B. and Ladd, A. C. (1962). Absorption and Excretion of Mercury in Man. I. Relationship of Mercury in Blood and Urine, Arch. Environ. Health, 5, 537.

2) Ladd, A. C., Goldwater, L. J. and Jacobs, M. B. (1963). Absorption and Excretion of Mercury in Man. II. Urinary Mercury in Relation to Duration of Exposure, Arch. Environ. Health, 6, 480.

3) Jacobs, M. B., Ladd, A. C. and Goldwater, L. J. (1963). Absorption and Excretion of Mercury in Man. III. Blood Mercury in Relation to Duration of Exposure, Arch. Environ. Health, 6, 634.

4) Goldwater, L. J., Jacobs, M. B. and Ladd, A. C. (1963).Absorption and Excretion of Mercury in Man. IV. Tolerance to Mercury, Arch. Eviron. Health, 7, 568.

5) Ladd, A. C., Goldwater, L. J. and Jacobs, M. B. (1964). Absorption and Excretion of Mercury in Man. V. Toxicity of Phenyl mercurials, Arch. Environ. Health, 9, 43.

6) Cherian, M. G., Hursh, J. B., Clarkson, T. W. and Allen, J. (1978). Radioactive Mercury Distribution in Biological Fluids and Excretion in Human Subjects after Inhalation of Mercury vapor, Arch. Environ. Health, 33, 109.

7) Hursh, J. B., Clarkson, T. W., Cherian, M. G., Vostal, J. J. and Mallie, R. V. (1976). Clearance of Mercury (Hg-197, Hg-203) Vapor Inhaled by Human Subjects, Arch. Environ. Health, 30, 302.

8) Magos, L. (1981). In Industrial and Environmental Xenobiotics (Edited by Gut, I., Cikrt, M. and Plaa, G. L.), p. 1, Springer-Verlag, New York.

9) Rentos, P. G. and Seligman, E. J. (1968). Relationship between Environmental Exposure to Mercury and Clinical Observation, Arch. Environ. Health, 16, 794.

10) Bell, Z. G. Jr., Wood, M. W. and Kuryla, L. A. (1973). Mercury Exposure Evaluations and their Correlation with Urine Mercury Excretions. 1. A Method to Determine Mercury Time-Weighted Average (TWA) Exposures, JOM, 15, 340.

11) Task Group on Environmental Health Criteria for Mercury. Environmental Health Criteria 1 Mercury. (1976). United Nations Environment Programme and the World Health Organization. Geneva, pp. 65, 68 and 114. 
12) Miettinen, J. K. (1973). In Mercury, Mercurials and Mercaptans. (Edited by Miller, M. W. and Clarkson, T. W.), p. 233, Springfield, Illinois.

13) Moffit, A. E. Jr. and Kupel, R. E. (1971). A rapid method employing impregnated charcoal and Atomic Absorption Spectrophotometry for the Determination of Mercury, Am. Ind. Hyg. Assoc. J., 32, 614.

14) Model 65 Vapor Generation Accessory. Operation Manual. February 1979. Varian Publication No. 85-100338-00.

15) Kranse, L. A., Henderson, R., Shotwell, H. P. and Culp, D. A. (1971). The analysis of mercury in urine, blood, water, and air, Am. Ind. Hyg. Assoc. J., 32, 331.

16) Berlin, A. and Schaller, K. H. (1974). European Standardized Method for the Determination of delta-Aminolevulinic Acid Dehydratase Activity in Blood, Z. Klin. Chem. Klin. Biochem., 12, 389.

17) Chisolm, J. J. Jr. and Brown, D. H. (1975). Micro-scale Photofluorometric Determination of "Free Erythrocyte Porphyrin" (Protoporphyrin IX), Clin. Chem., 21, 1669.

18) Leidel, N. A., Busch, K. A., Lynch, J. R. (1977). In Occupational Exposure Sampling Strategy Manual, U.S. Department of Health, Education, and Welfare (NIOSH Publication No. 77-173). Ohio, U.S.A.

19) Hesley, K. L. and Wimbish, G. H. (1981). Blood lead and zinc protoporphyrin in lead industry workers, Am. Ind. Hyg. Assoc. J., 42, 42.

20) Tola, S. (1973). Erythrocyte Delta-Aminolevulinic Acid Dehydratase as a Test for Lead Exposure. Academic Dissertation. Instiute of Occupational Health, Helsinki, Finland. (Note: This issue has 4 articles on ALA-D discussion).

21) Woodcock, S. M. (1958). A case illustrating the effect of calcium disodium Versenate ( $\mathrm{CaNa}_{2}$-EDTA) on chronic mercury poisoning, Br. J. Ind. Med., 15, 207.

22) Tandon, S. K. and Magos, L. (1980). Effect of kidney damage on the mobilization of mercury by thiol-complexing agents, Br. J. Ind. Med., 37, 128. 